\title{
Dirvožemio terminis režimas Lietuvoje
}

\section{Viktorija Mačiulytė,}

\section{Egidijus Rimkus}

Vilniaus universitetas,

M. K. Čiurlionio g. 21, LT-03101 Vilnius

El.paštas:viktorija.maciulyte@gf.vu.lt; egidijus.rimkus@gf.vu.lt
Mačiulytė V., Rimkus E. Dirvožemio terminis režimas Lietuvoje. Geologija. Geografija. 2016. T. 2(1). ISSN 2351-7549.

Tyrimo tikslas - išnagrinèti dirvožemio temperatūros režimą bei sąsajas su oro temperatūra ir sezoninio dirvožemio išalo rodikliais Lietuvos teritorijoje. Tyrime panaudoti 17 Lietuvos meteorologijos stočių išmatuoti dydžiai. Analizuojama dirvožemio temperatūros iki 3,2 m gylio kaita per metus (1981-2010), daugiametés kaitos tendencijos (1961-2010), dirvožemio temperatūros ryšys su oro temperatūra bei maksimaliu įšalo gyliu ir trukme. Nustatyta, kad dirvožemio temperatūra glaudžiai koreliuoja su oro temperatūra, o gilesniuose sluoksniuose temperatūros svyravimai vèluoja paviršiaus atžvilgiu. Analizuojamuoju laikotarpiu greičiausiai augo vidutine metinè paviršiaus temperatūra (vidutiniškai $0,4{ }^{\circ} \mathrm{C}$ per dešimtmetị), o gilesniuose dirvožemio sluoksniuose šis dydis kito nuo 0,26 ( $0,2 \mathrm{~m}$ gylyje) iki $0,29^{\circ} \mathrm{C}$ per dešimtmeti $(0,8 \mathrm{~m}$ gylyje). Teigiami statistiškai reikšmingi pokyčiai visoje Lietuvos teritorijoje dirvožemio paviršiuje nustatyti balandžio mèn., 0 didesneje jos dalyje - gegužę, liepą ir rugpjūtị. Neigiami statistiškai nereikšmingi pokyčiai beveik visoje Lietuvoje užfiksuoti spali, o birželį - pusèje šalies teritorijos. Gilesniuose sluoksniuose fiksuojami tik teigiami temperatūros pokyčiai, kurių absoliuti dauguma yra statistiškai reikšmingi. Dirvožemio iš̌alo rodikliai priklauso nuo šaltojo laikotarpio (lapkričio-balandžio) oro temperatūros. Augant šaltojo sezono oro temperatūrai, ̨̧šalo trukmè 1961-2010 m. visoje šalies teritorijoje statistiškai reikšmingai sumažèjo (vidutiniškai 9 dienomis per dešimtmetị). Vidutinis maksimalus ịšalo gylis taip pat sumažejo (vidutiniškai $8 \mathrm{~cm}$ per dešimtmetị), o daugumoje meteorologijos stočių pokyčiai yra statistiškai reikšmingi.

Raktažodžiai: dirvožemio temperatūra, sezoninis dirvožemio iš̌alas, klimato pokyčiai

\section{IVADAS}

Paklotinis paviršius yra labai svarbus klimato sistemos komponentas (Luo ir kt., 2003), o dirvožemis, kaip viena iš pagrindinių paviršiaus dalių, aktyviai sąveikauja su atmosfera, biosfera ir hidrosfera. Vienas iš dirvožemị apibūdinančių rodiklių yra jo paviršiaus ir paviršinio sluoksnio temperatūra. Dirvožemio terminis režimas priklauso nuo jo fizinių savybių, granuliometrinès sudèties, drègmès kiekio ir kt. (Galvonaite ir kt., 2007). Taip pat dirvožemio temperatūra priklauso nuo Saulès spinduliuotès intensyvumo, šiltų ar šaltų oro masių advekcijos.
Dirvožemio temperatūra daro ittaką daugeliui svarbių procesų, vykstančių gamtoje (Lehnert, 2014). Nuo dirvožemio temperatūros priklauso biocheminiai procesai, tokie, kaip ištirpusios organinès anglies pernešimas (Haei ir kt., 2010). Nustatyta, kad dirvožemio temperatūra turi ryši su $\mathrm{CO}_{2}$ ir $\mathrm{NO}_{2}$ emisija: šylant dirvožemiui šių dujų išskyrimas $\mathfrak{i}$ atmosferą didejja. Taigi šis efektas tampa teigiamu grịžtamuoju ryšiu klimato sistemoje (Haei ir kt., 2013; Lu, Xu, 2014; Albergel ir kt., 2015).

Dirvožemio terminis režimas itin svarbus rodiklis žemès ūkiui. Vidutinèse ir aukštosiose platumose augalams svarbus vasarą dirvožemyje sukaupiamos šilumos kiekis, o rudenị ir žiemą - ị̌salo 
gylis bei sniego dangos storis. Dirvožemio temperatūra daro ịtaką augalų šaknų sistemos vystymosi greičiui ir energijai, dèl kurios šaknys prasiskverbia ì dirvožemị. Nuo šaknų sistemos priklauso tolesnis augalo augimas ir vystymasis (Kaspar, Bland, 1992).

Dirvožemio temperatūra taip pat daro ịtaką augalijos vegetacijos sezono trukmei (Euskirchen ir kt., 2006; Öquist, Laudon, 2008; Lehnert, 2014), mineralizacijos greičiui (Haei ir kt., 2013), organinès medžiagos dirvožemyje irimui (Davidson, Janssens, 2006), maisto medžiagų ìsisavinimui augaluose (Domisch ir kt., 2001; Melillo ir kt., 2002), miškų produktyvumui (Strömgren, Linder, 2002) ir kt.

Keičiantis globaliam klimatui kyla ne tik oro, bet ir dirvožemio temperatūra. Nustatyta kad dèl kylančios oro temperatūros didžiausias poveikis dirvožemio terminiam režimui bus jaučiamas borealiniuose regionuose su sezonine sniego danga (Jungqvist ir kt., 2014). Nors dirvožemio ir oro temperatūra susieta glaudžiais ryšiais, tačiau daugiametès kaitos tendencijos nebūtinai turi sutapti (Gilichinsky ir kt., 1998). Dèl plonejjančios sniego dangos dirvožemis gali stipriau ǐšalti, todèl kai kuriais šaltojo sezono mènesiais gali būti fiksuojamas dirvožemio temperatūros mažejimas (Stieglitz ir kt., 2003; Maljanen ir kt., 2007; Brown, DeGaetano, 2011; Qian ir kt., 2011). Nustatyta, kad kylant oro temperatūrai, dirvožemio temperatūra gali kisti mažiau ir dèl didèjančio vasaros kritulių kiekio (Zhang ir kt., 2001; Beniston, Diaz, 2004).

Dirvožemis iš esmès yra neatsinaujinantis ekosistemos komponentas (Feizienè ir kt., 2009). Jo pažeidžiamumas dideja ne tik dèl klimato kaitos, tačiau ir dèl žmogaus ūkinès veiklos: didejjant jo druskingumui, rūgštingumui, eutrofikacijai ir erozijai (Blum, 2005).

Borealinèse platumose dirvožemio terminiams režimo tyrimams yra skiriama itin daug demesio. Ypač daug tyrimų atlikta Rusijoje, Skandinavijoje, Kanadoje (Glichinsky ir kt., 1998; Zhang ir kt., 2005; Helama ir kt., 2011; Park ir kt., 2014). Beveik visų tyrimų rezultatai rodo, kad pastaraisiais dešimtmečiais dirvožemio temperatūra auga, o sezoninio dirvos ǐšlo rodikliai (maksimalus gylis bei išalo trukmè) mažèja (Frauenfeld, Zhang, 2011; Helama ir kt., 2011).

Lietuvoje taip pat yra atlikta dirvožemio temperatūros (Bukantis, 1994; Važnevičiūtè, 2007;
Galvonaite ir kt., 2007) bei sezoninio išsalo gylio ir trukmès rodikliu tyrimu (Taminskas ir kt., 2005; Taminskas ir kt., 2006; Krotovas, 2012). J. Taminskas su bendraautoriais $(2005,2006)$ nustatè, kad $\mathrm{XX}$ a. pabaigoje mažèjo tiek maksimalus įšalo storis, tiek jo trukmè.

Tačiau kol kas menkai tirtos sąsajos tarp oro ir dirvožemio temperatūros bei ǰšalo gylio. Mažai dèmesio skirta dirvožemio temperatūros įvairiuose gyliuose daugiametès kaitos Lietuvos teritorijoje analizei. Todèl šio tyrimo tikslas - išnagrinèti dirvožemio temperatūros režimą ịvairiuose gyliuose bei jo sąsajas su oro temperatūra ir sezoninio ịšalo rodikliais Lietuvoje, taip pat ištirti dirvožemio temperatūros kaitos tendencijas 1961-2010 metais.

\section{DUOMENYS IR METODIKA}

Atliekant ši tyrimą analizuojami meteorologiniai rodikliai, išmatuoti Lietuvos hidrometeorologijos tarnybos tinklui priklausančiose meteorologijos stotyse (toliau MS) (1 pav.): oro temperatūra, dirvožemio paviršiaus temperatūra, dirvožemio temperatūra $0,2,0,8,1,6$ ir 3,2 m gyliuose, dienų su išalu skaičius ir maksimalus ịšalo gylis. Matavimų 17 meteorologijos stočiu duomenys gauti iš Lietuvos hidrometeorologijos tarnybos prie Aplinkos ministerijos archyvų.

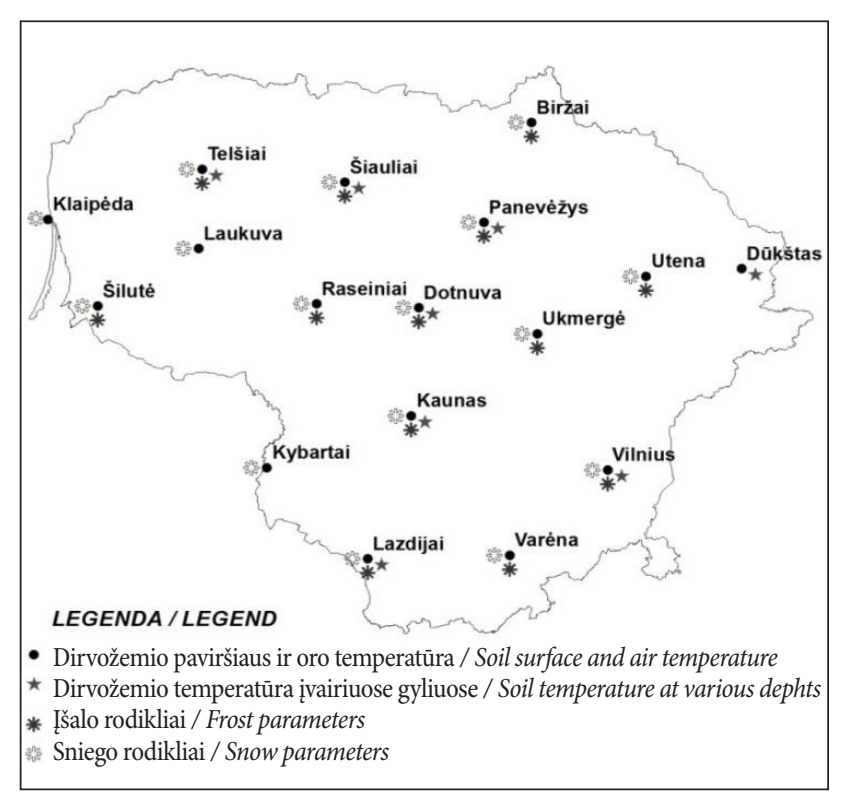

1 pav. Tyrime naudoti meteorologiniai rodikliai ir meteorologijos stočiu vieta

Fig. 1. Location of meteorological stations whose data were used in the study and investigated meteorological indices 
Oro ir dirvožemio paviršiaus temperatūros matavimai atlikti skysčio termometrais, o ịvairiuose dirvožemio gyliuose - giluminiais ištraukiamaisiais TM-10 termometrais aikšteleje su natūralia žoline danga. Gilesnių dirvožemio sluoksnių temperatūra analizuojamuoju laikotarpiu matuota aštuoniose stotyse. Dūkšte tokie matavimai pradèti tik 1970 m., todèl šios stoties duomenys panaudoti skaičiuojant tik vidutines 1981-2010 m. reikšmes.

Dirvožemio tipas stotyse, kuriose analizuoti temperatūros pokyčiai ịvairiuose gyliuose, skiriasi. Remiantis Lietuvos hidrometeorologijos tarnybos duomenimis Dotnuvoje, tai velèniniai glejjiniai priemoliai; Dūkšte - velèninis jaurinis vidutiniškai nujaurejęs molis; Kaune - velèninio karbonatinio nujaurejusio molio uolienos; Lazdijuose - velèninis karbonatinis žvyras ant priemolio; Panevėžyje - velèninis glejiškas išplautas vidutinis priemolis; Šiauliuose - velèninis jaurinis silpnai nujaurèjęs smèlis ant priemolio; Telšiuose - velèninis jaurinis mažai nujaurèjęs nuardytas priemolis; Vilniuje - velèninis karbonatinis išplautas žvyras.

Sniego dangos matavimai atlikti stacionaria matuokle, irengta meteorologijos stotyje, o izšalo gylio - pašalomačiu.

Analizuojamasis laikotarpis - 1961-2010 m., tačiau kai kuriose stotyse matavimai pradèti véliau. Oro temperatūrą Dotnuvoje imta matuoti 1963 m., 3,2 m gylio temperatūrą Lazdijuose - 1987 metais. Dūkšte dirvožemio temperatūra ìvairiuose gyliuose pradèta matuoti 1970 m., oro temperatūra - 1972 metais. Analizuojamasis laikotarpis iki 2010 m., nes dèl atlikto Lietuvos meteorologijos stočiu tinklo pertvarkymo dalis meteorologinių rodiklių nebèra matuojami.

Pradinių matavimo duomenų trūkiai užpildyti naudojant tame pačiame klimatiniame rajone esančios atraminès stoties duomenis, su kuria rekonstruojamos stoties matavimo rezultatus sieja glaudžiausias koreliacinis ryšys. Užpildant trūkius buvo remiamasi vidutiniu skirtumu tarp rekonstruojamos ir atraminès stoties duomenų sekų vidurkių.

Tyrime analizuojama dirvožemio temperatūros iki 3,2 m gylio kaita per metus 1981-2010 m. bei daugiametes kaitos tendencijos 1961-2010 metais. Taip pat ịvertintas dirvožemio temperatūros ryšys su oro temperatūra bei maksimaliu ìšalo gyliu ir trukme. Nustatytos dirvožemio įšalo rodiklių daugiametès kaitos tendencijos ir sąsajos su oro temperatūra.

Koreliacinè analizé atlikta siekiant ịvertinti ryšius tarp ịvairių gylių dirvožemio temperatūros, oro temperatūros, dirvožemio į̌salo rodiklių. Analizuotos sąsajos tarp tiriamųjų parametrų tiek bejgant laikui, tiek erdvejje. Itvertintas Pirsono tiesinès koreliacijos koeficientų statistinis reikšmingumas (jie laikyti statistiškai reikšmingais, kai $p<0,05)$.

Daugiametès analizuojamujų rodikliu kaitos tendencijos, nustatytos tiesinès regresijos pagalba, o pokyčių per analizuojamąji 1961-2010 m. laikotarpi dydžiai apskaičiuoti remiantis regresijos koeficientų reikšmèmis. Pokyčių statistinis reikšmingumas ivertintas Stjudento kriterijumi (statistiškai reikšmingais laikyti tie pokyčiai, kurių atsitiktinio susidarymo galimybè mažesnè nei $0,05)$.

\section{VIDUTINĖ DIRVOŽEMIO TEMPERATŪRA 1981-2010 M. IR SĄSAJOS SU ORO TEMPERATÜRA}

1981-2010 m. vidutinè metinè dirvožemio paviršius temperatūra Lietuvoje buvo lygi $7,9^{\circ} \mathrm{C}$ ir kito nuo $7,1^{\circ} \mathrm{C}$ Dūkšto MS iki $9,7^{\circ} \mathrm{C}$ Klaipedos MS. Žiemos metu dèl šildančio Baltijos jūros poveikio dirvožemio paviršiaus temperatūra dideja artejjant jūros link ir pajūrio regione yra aukštesnè nei $-2,5^{\circ} \mathrm{C}$, o šalies šiaurès rytuose nukrinta žemiau $-4,5{ }^{\circ} \mathrm{C}$ (2a pav.). Vasarą vidutiniškai aukščiausia dirvožemio temperatūra fiksuojama Klaipèdos MS (dèl ilgesnès Saulès spindèjimo trukmès bei greitai išylančio smèlinio dirvožemio) ir Pietų Lietuvoje. Čia lemiamą vaidmenị vaidiną didesnis Saulès pakilimo kampas bei mažesne šilumine talpa pasižymintys smèlio ir lengvo priemolio dirvožemiai. Tuo tarpu Panevèžyje ir Raseiniuose, kur vyrauja léčiau dienos metu išylantis vidutinis ir sunkus priemolis, vidutine vasaros dirvožemio paviršiaus temperatūra yra mažiausia.

Vidutiniškai žemiausia dirvožemio temperatūra Lietuvoje $1981-2010 \mathrm{~m}$. buvo vasarị $\left(-4,0^{\circ} \mathrm{C}\right)$, o aukščiausia - liepą $\left(21,8{ }^{\circ} \mathrm{C}\right)$. Klaipedoje liepą dirvožemis vidutiniškai sušyla iki $24{ }^{\circ} \mathrm{C}$. Šilumos perdavimo ị dirvožemio gilumą (ar ì paviršių šaltuoju metu laiku) greitis priklauso nuo vertikalaus 


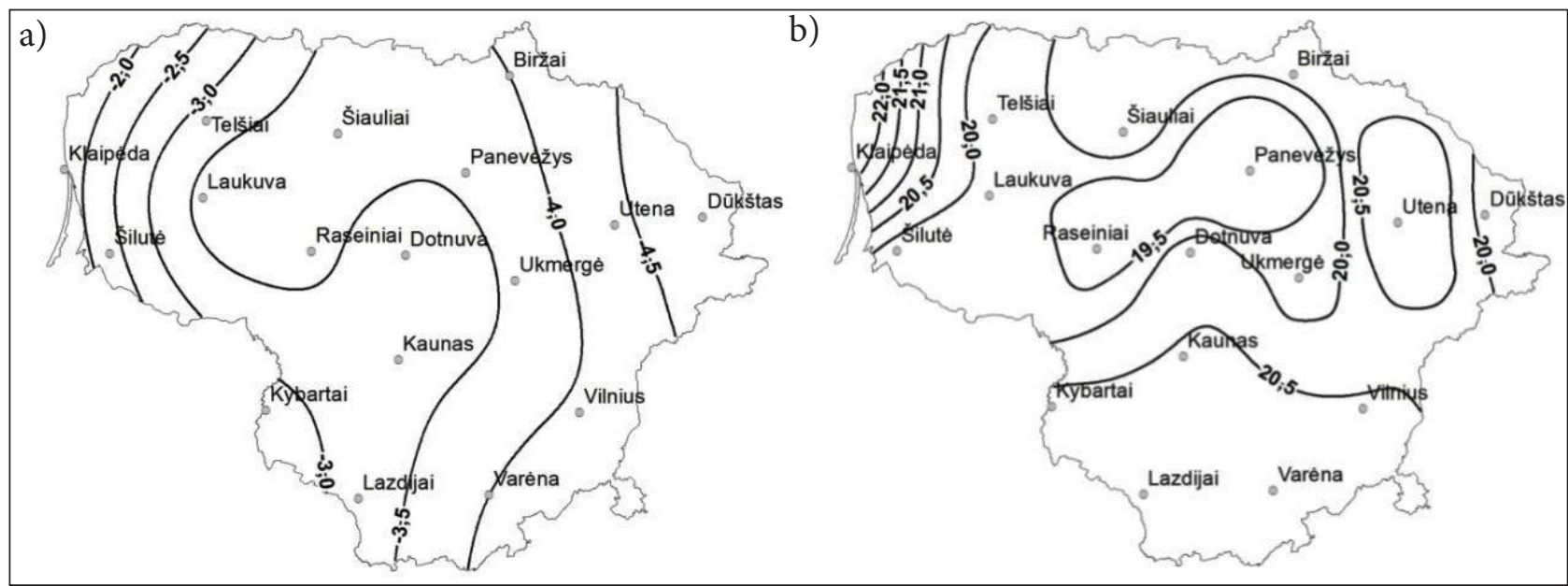

2 pav. Vidutinė dirvožemio paviršiaus temperatūra $\left({ }^{\circ} \mathrm{C}\right)$ žiemą (a) ir vasarą (b) 1981-2010 m.

Fig. 2. Mean soil surface temperature $\left({ }^{\circ} \mathrm{C}\right)$ in winter (a) and summer (b) in 1981-2010

temperatūros gradiento dirvožemyje, kuris didèjant gyliui dažniausiai mažèja. Todèl šilumos srauto intensyvumas gilèjant mažeja, dèl to mažèja ir metinè dirvožemio temperatūros amplitudè (3 pav.). Be to, šilumos perdavimas vyksta ribotu greičiu, kuris priklauso nuo dirvožemio šilumos laidumo, todèl ekstremumų laikas paviršiuje bei gilesniuose sluoksniuose nesutampa.

Vidutinè metiné temperatūra $0,2,0,8,1,6$ ir 3,2 m gylyje Lietuvoje (apskaičiuota iš septynių meteorologijos stočių duomenų) yra vienoda $-8,3{ }^{\circ} \mathrm{C}$. Vidutinè minimali temperatūra visose stotyse 0,2 ir $0,8 \mathrm{~m}$ gylyje yra fiksuojama vasari, $1,6 \mathrm{~m}$ gylyje - kovą, o balandi - 3,2 m gylyje. Maksima- li - 0,2 m gylyje liepą, 0,8 ir 1,6 m gylyje - rugpjūtị, o 3,2 m gylyje - rugsèji (3 pav.).

Vidutiniškai Lietuvoje $0,2 \mathrm{~m}$ gylyje metinè temperatūros svyravimo amplitudè siekia $18,2^{\circ} \mathrm{C}, 0,8 \mathrm{~m}$ gylyje $-14,5^{\circ} \mathrm{C}, 1,6 \mathrm{~m}$ gylyje $-11,2^{\circ} \mathrm{C}$, o $3,2 \mathrm{~m}$ gylyje $-6,7^{\circ} \mathrm{C}$. Didžiausia amplitudè visuose gyliuose nustatyta Vilniuje, o mažiausia (išskyrus $0,2 \mathrm{~m}$ gylì) - Šiauliuose. Tai sietina su tuo, kad Vilniuje esantis žvirgždas yra laidesnis šilumai, nei priemolis Šiauliuose. Nors žvirgždo šiluminis laidumas yra didelis, tačiau talpa maža, todèl Vilniuje dirvožemis vasarą stipriau ǐšyla, o žiemą stipriau atvėsta, palyginti su kitomis, matuoto dirvožemio temperatūros ivairiuose gyliuose, vietovemis.

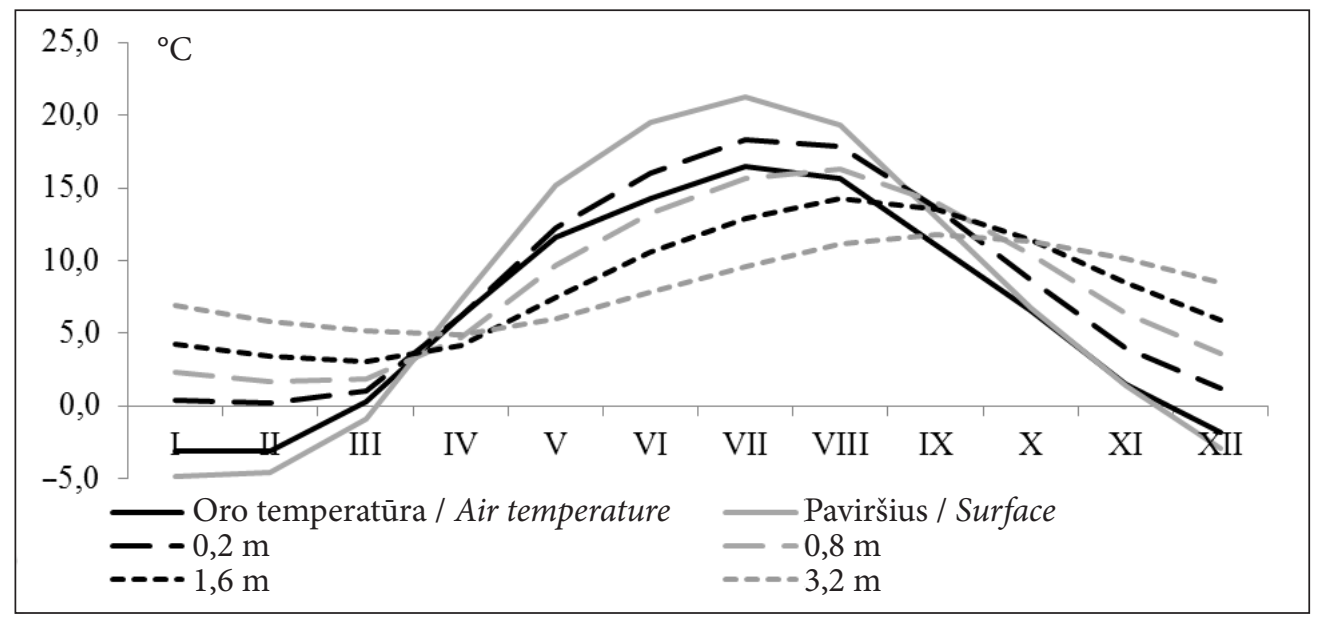

3 pav. Dirvožemio įvairiuose gyliuose ir oro temperatūros $\left({ }^{\circ} \mathrm{C}\right)$ kaita per metus Lietuvoje 1981-2010 m.

Fig. 3. Intra-anual variation of soil temperature $\left({ }^{\circ} \mathrm{C}\right)$ at various depths and air temperature $\left({ }^{\circ} \mathrm{C}\right)$ in Lithuania in 1981-2010 
Analizuojant dirvožemio temperatūros įvairiuose gyliuose erdvini ryši nustatyta, kad teritoriniu požiūriu dirvožemio temperatūros reikšmes sieja statistiškai reikšmingi stiprūs ir labai stiprūs ryšiai. Vidutinès metinès dirvožemio paviršiaus temperatūros koreliacija tarp stočių kinta nuo 0,89 iki 0,99 , o gilesniuose dirvožemio sluoksniuose - nuo 0,68 iki 0,96 . Ryšio glaudumas priklauso nuo atstumo tarp stočiu bei dirvožemio sudèties vienodumo. Analizuojant atskirus ménesius nustatyta, kad stipriausias ryšys fiksuojamas rudenị ir žiemą, kai Lietuvos orai daugiausia priklauso nuo oro masiu advekcijos. Tuo tarpu antroje pavasario puseje bei vasarą išauga vietos veiksnių (tarp jų ir dirvožemio tipo) poveikis terminiam režimui, todèl koreliacija tarp stočių susilpnèja, nors vis dar išlieka stipri.

Vidutiniškai meteorologijos stotyse išmatuota vidutinė metinė dirvožemio temperatūra yra apie $1,5{ }^{\circ} \mathrm{C}$ aukštesnè nei oro temperatūra. Tačiau šis skirtumas atskirais metų mènesiais yra nevienodas (3 pav.). Balandžio-rugsėjo mèn., kai dirvožemio paviršius dienos metu yra stipriai ǐšildomas tiesioginių Saulès spindulių, vidutiné dirvožemio temperatūra yra didesnè nei oro. Birželio-liepos mèn. (kai Saule pakyla aukščiausiai) šis skirtumas Lietuvos teritorijoje vidutiniškai viršija $3,5{ }^{\circ} \mathrm{C}$. Šiuo metų laiku didelè gaunamos energijos dalis yra sunaudojama gilesniems dirvožemio sluoksniams šildyti. Tuo tarpu spalį-kovą, kai suminis gaunamos Saulès spinduliuotès kiekis yra labai mažas, dirvožemis atvėsta, ir jo temperatūra yra žemesnè nei oro. Be to, kovo mèn. didelè dalis spindulinès energijos, patenkančios ant dirvožemio paviršiaus, yra panaudojama drégmei nuo dirvos paviršiaus garinti. Oro temperatūra žiemos mènesiais yra didesnè nei dirvožemio paviršiaus (paviršiaus temperatūra matuojama ant sniego paviršiaus) dèl vyraujančios vakarinès oro pernašos ir santykinai šiltų jūrinių oro masių advekcijos. Šaltuoju metų laikotarpiu dirvožemio ir oro temperatūros skirtumas yra mažesnis nei vasarą ir daugumoje meteorologijos stočių neviršija $1{ }^{\circ} \mathrm{C}$.

Vidutinè metinè dirvožemio temperatūra 0,2 metrų gylyje taip pat yra didesnè nei oro, tik šiuo atveju vidutinis skirtumas siekia $2,0{ }^{\circ} \mathrm{C}$. Priešingai nei lyginant su paviršiumi, šis skirtumas žiemą yra teigiamas ir viršija $3{ }^{\circ} \mathrm{C}$. Dirvožemị šiame gylyje nuo atvėsimo saugo sniego danga, be to, tam tikras šilumos kiekis gaunamas iš gilesnių dirvožemio sluoksnių. Tik pavasarị dirvožemio tempe- ratūra šiame gylyje yra šiek tiek žemesnè nei oro, nes nemaža dalis pavasari gaunamos energijos yra sunaudojama išalui tirpdyti bei drègmei garinti. Be to, antroje pavasario pusejje gilesni dirvožemio sluoksniai yra vèsesni, todèl šilumos srautas būna nukreiptas žemyn. Gilesniuose dirvožemio sluoksniuose $(0,8,1,6$ ir 3,2 $\mathrm{m})$ balandžio-rugsèjo dirvožemio temperatūra yra žemesnè nei oro, o likusiais metų ménesiais - aukštesnè.

Tyrimo metu nustatyta, kad dirvožemio paviršiaus bei $0,2 \mathrm{~m}$ gylio temperatūra beveik visose meteorologijos stotyse visais metu mènesiais geriausiai siejasi su to paties ménesio oro temperatūra. Šiltuoju metų laiku (balandis-spalis) daugumos koreliacijos koeficientų reikšmès viršija 0,8 , o žiemą šis ryšys yra silpnesnis. Kai kuriose meteorologijos stotyse kovo bei balandžio mèn. dirvožemio temperatūra stipriau susijusi su pirmosios žiemos pusès oro temperatūra. Tai sietina su sniego dangos (esant storai sniego dangai šis ryšys silpsta, nes mažèja šilumos apykaita tarp oro ir dirvožemio) bei ìšalo (dalis dirvožemyje sukauptos energijos yra panaudojama įšlui tirpdyti bei drègmei garinti) poveikiu. Su to paties mènesio oro temperatūra geriausia siejasi dirvožemio temperatūra $0,8 \mathrm{~m}$ gylyje. Tačiau šiuo atveju koreliacijos koeficientai beveik visais metų mènesiais kinta nuo 0,5 iki 0,8. 1,6 m gylyje stipriausias ryšys dirvožemio temperatūrą dažniausiai sieja su vienu mènesiu anksčiau fiksuota oro temperatūra (nors atskirais atvejais glaudžiausiai koreliuoja ir su to paties ménesio temperatūra), o 3,2 m gylyje - su prieš 2-4 mènesius buvusia oro temperatūra. Visi paminèti ryšiai yra statistiškai reikšmingi, o 1,6 ir 3,2 m gylyje glaudžiausią ryši apibūdinančių koreliacijos koeficientų reikšmès dažniausiai kinta nuo 0,4 iki 0,7 .

\section{DIRVOŽEMIO TEMPERATŪROS RYŠYS SU SEZONIO İŠALO RODIKLIAIS}

Vidutinis dienų su sezoniniu išalu skaičius Lietuvoje 1981-2010 m. kito nuo mažiau nei 90 dienu pajūryje iki daugiau nei 115 dienų šalies šiaurès rytuose (4a pav.). Vidutiniškai ilgiausia ǐšalo trukmè 1961-2010 m. šalies teritorijoje užfiksuota 1969 (164 dienos), o trumpiausia - 2009 m. (52 dienos). Didžiausias vidutinis išsalo gylis nustatytas Lazdijuose $(55 \mathrm{~cm})$ ( $4 \mathrm{~b}$ pav.). Tai sietina su gana dideliu sniego dangos nepastovumu ir mažu jo storiu pietvakarių Lietuvoje, taip pat kad čia vyrauja 


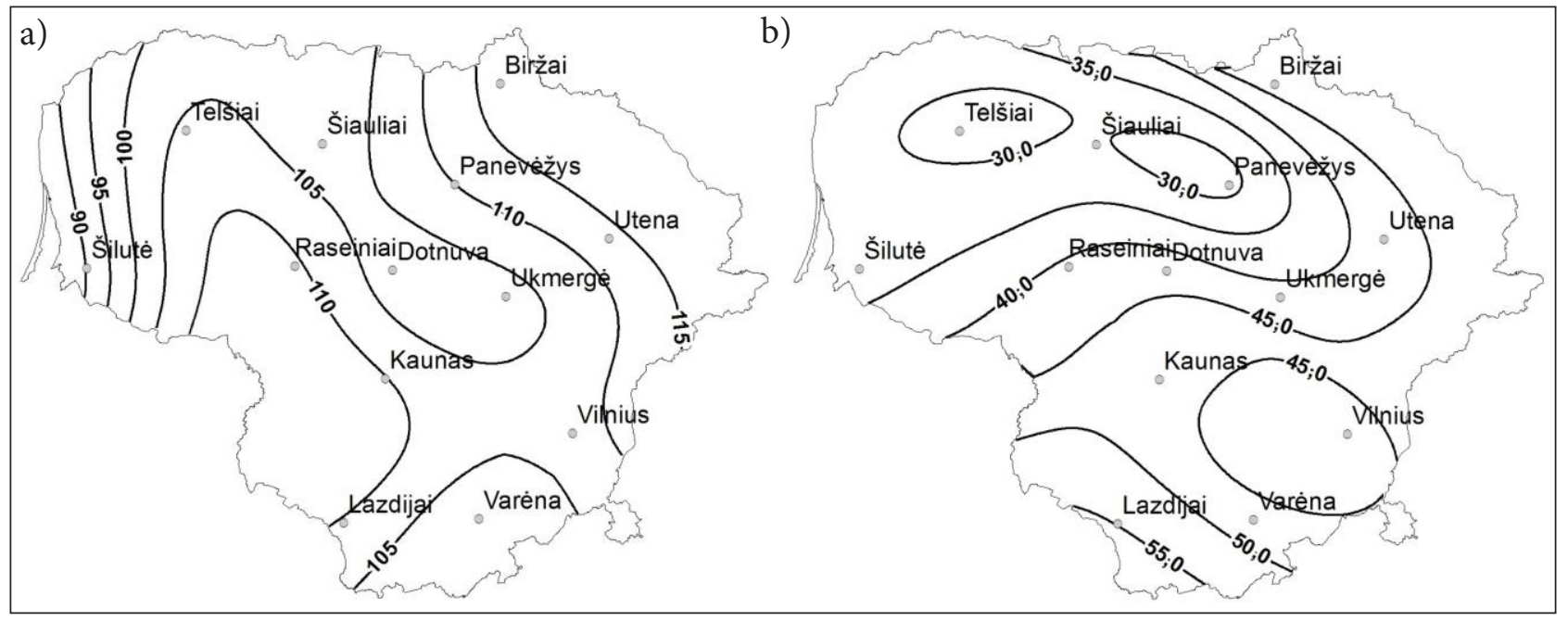

4 pav. Dienų su įšalu skaičius (a) ir maksimalus dirvožemio ịšalo gylis (cm) (b) 1981-2010 m. Lietuvos teritorijoje Fig. 4. Mean soil frost duration (a) and mean maximal soil frost depth (b) in Lithuania in 1981-2010

giliai įšąlantys sausi smèlio dirvožemiai. Todèl šalies teritorijoje nusistovejus šaltiems orams į̌salo storis gali greitai išaugti. Pačios mažiausios vidutinès į̌salo storio reikšmès užfiksuotos Panevėžyje $(29 \mathrm{~cm})$. Mažos ižšalo storio reikšmès išmatuotos ir Telšiuose dèl Žemaičių aukštumai būdingos storos sniego dangos. 1969 m. išsiskyrè ir pačiu didžiausiu vidutiniu maksimaliu įšalo gyliu Lietuvoje $(117 \mathrm{~cm})$, o $1972 \mathrm{~m}$. - mažiausiu $(21 \mathrm{~cm})$.

İšalo trukmè priklauso nuo šaltojo laikotarpio oro temperatūros. Koreliacijos koeficiento, siejančio vidutinę šalies lapkričio-balandžio mèn. oro temperatūrą su vidutine įšalo trukme (apskaičiuota iš trylikos meteorologijos stočių duomenų), reikšmé siekia $-0,72$ (5a pav.). Atskirose meteorologijos stotyse šis dydis svyruoja nuo $-0,61$ (Vilniuje) iki $-0,72$ (Kaune). Ǐšalo trukmé statistiškai reikšmingai koreliuoja su vidutine visų šio periodo mènesių oro temperatūra, o glaudžiausias ryšys Lietuvos teritorijoje nustatytas vasarị-kovą $(r<-0,5)$.

Išsalo trukmè glaudžiai koreliuoja ir su maksimaliu išsalo gyliu $(r=-0,65)$ (5c pav.). Meteorologijos stotyse koreliacijos koeficiento reikšmè kinta nuo $-0,68$ (Ukmergèje) iki -0,46 (Biržuose). İšalo gylis taip pat geriausiai siejasi su vidutine lapkričio-balandžio mèn. oro temperatūra $(r=-0,71)$ (5b pav.). Sausį-kovą koreliacijos koeficientų reikšmès yra žemesnès nei $-0,5$, tačiau ryšys tarp lapkričio mèn. oro temperatūros ir maksimalaus įšalo gylio nèra statistiškai reikšmingas. Nors lapkritị išalas susiformuoja retai, tačiau šio ménesio temperatūra lemia dirvožemio temperatūrą gilesniuose sluoksniuose žiemos mėnesiais. Kita vertus, iki balandžio mėn. išalas išsilaiko ne kiekvienais metais, tačiau būtent pirmos pavasario pusès sąlygos labai stipriai lemia išalo rodiklius. Atskirose meteorologijos stotyse koreliacijos koeficientų reikšmès kinta nuo -0,74 (Utenoje) iki -0,46 (Šiluteje). Gana silpną ryši Šilutëje galima sieti su sniego dangos nepastovumu Vakaru Lietuvoje - čia santykinai storas įšalo sluoksnis gali susiformuoti net ir esant ne itin žemai (palyginti su likusia šalies teritorija) oro temperatūrai.

Analizuojant ryši tarp dirvožemio temperatūros įvairiuose gyliuose ir maksimalaus išalo gylio nustatyta, kad statistiškai reikšmingas neigiamas koreliacinis ryšys šiuos rodiklius visuose gyliuose sieja sausio-balandžio mėnesiais. Priežastingumas šiuo laikotarpiu kinta. Jei žiemos pradžioje oro ir dirvožemio temperatūra lemia ìšalo storị, tai pavasarị priešingai - storas žiemą susiformavęs išalas neleidžia dirvožemiui greitai ǐšilti, nes didelis gaunamos energijos kiekis yra sunaudojamas tirpinant išalą ir garinant drègmę. $0,2 \mathrm{~m}$ gylyje daugumoje Lietuvos meteorologijos stočių glaudžiausias ryšys sieja maksimalų itšalo gylį su vasario mèn., o gilesniuose sluoksniuose $(0,8-3,2 \mathrm{~m})$ - su balandžio mèn. dirvožemio temperatūra. Kovą-balandị greičiau atitirpsta paviršinis dirvožemio sluoksnis, ir temperatūros svyravimus jame labiau lemia Saulès spinduliuotès intensyvumas bei tai, kokių (šiltų ar šaltų) oro masių advekcija vyrauja.

Gilesnių dirvožemio sluoksnių temperatūros sąsajos su maksimaliu ìšalo storiu lieka labai glaudžios. Kad šilumos perdavimas gilyn dirvožemyje 


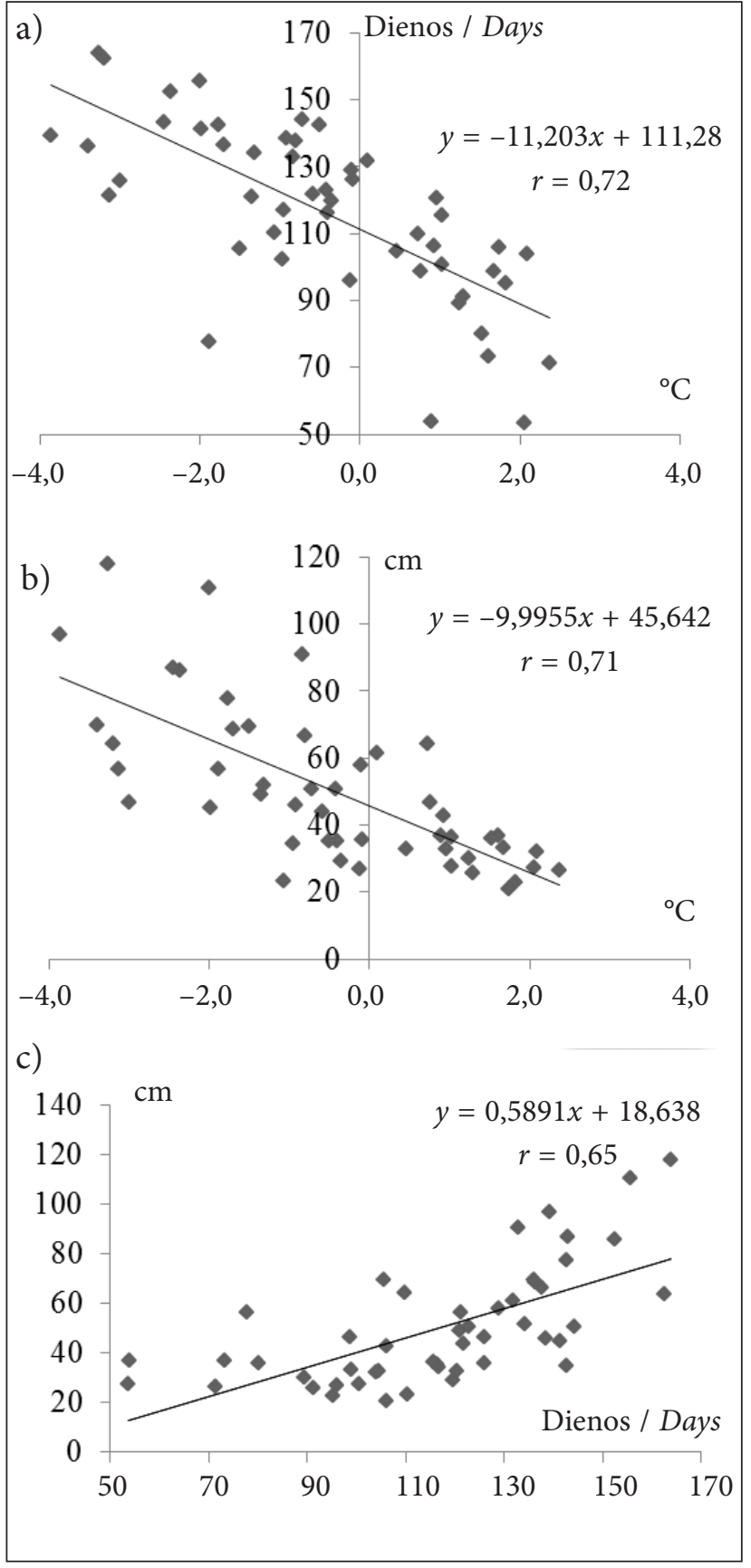

5 pav. Vidutinès lapkričio-balandžio mèn. oro temperatūros Lietuvos teritorijoje ryšys su vidutine išalo trukme (a), išalo gyliu (b) bei ryšys tarp įšalo trukmès ir gylio (c)

Fig. 5. Relationship between mean air temperature in November-April in Lithuania and mean soil frost duration (a), mean soil frost depth (b) and relationship between mean soil frost duration and mean soil frost depth (c) in 1961-2010

vyksta ribotu greičiu, gilesniuose sluoksniuose i paviršiaus temperatūros svyravimus reaguojama pavèluotai. Dẻl šių priežasčių $0,8 \mathrm{~m}$ gylyje statistiškai reikšmingas ryšys fiksuojamas ir gegužę,
1,6 m - gegužę ir birželį, o 3,2 m gylyje statistiškai reikšmingas neigiamas ryšys išsilaiko visus metus. Iš kitų Lietuvos stočių išsiskiria Dotnuvos MS, kur žiemos metu analizuojamuosius rodiklius statistiškai reikšmingi ryšiai sieja tik paviršiuje ir $3,2 \mathrm{~m}$ gylyje, o balandi - šis ryšys glaudus visuose analizuotuose gyliuose.

Koreliacijos koeficientai, siejantys vidutinę sausio-balandžio mẻn. dirvožemio temperatūrą įvairiuose gyliuose su vidutiniu maksimaliu ịšalo gyliu (apskaičiuota iš septynių meteorologijos stočiu duomenų), kinta nuo -0,67 (3,2 m gylyje) iki -0,83 ( $0,8 \mathrm{~m}$ gylyje). $80 \mathrm{~cm}$ gylyje įšalas sukausto žemę gana retai (ypač pastaraisiais dešimtmečiais), tačiau temperatūros svyravimai šiame gylyje yra glaudžiai susiję su aukštesnių dirvožemių sluoksnių terminiu režimu.

\section{DIRVOŽEMIO TEMPERATŪROS DAUGIAMETĖS KAITOS TENDENCIJOS}

Analizuojant vidutinès metinès dirvožemio temperatūros kaitą 1961-2010 m. nustatyta, kad greičiausiai auga paviršiaus temperatūra (vidutiniškai $0,4{ }^{\circ} \mathrm{C}$ per dešimtmeti) , o gilesniuose dirvožemio sluoksniuose šis dydis kinta nuo 0,26 (0,2 $\mathrm{m}$ gylyje) iki $0,29^{\circ} \mathrm{C}$ per dešimtmeti $(0,8 \mathrm{~m}$ gylyje). Visi pokyčiai (išskyrus kaitos tendencijas dirvožemio paviršiuje Šilutèje) yra statistiškai reikšmingi (lentelè). Sparčiausi pokyčiai dirvožemio paviršiuje užfiksuoti Kaune ir Klaipédoje $\left(0,49{ }^{\circ} \mathrm{C}\right.$ per dešimtmetį), o gilesniuose sluoksniuose kiek didesni pokyčiai užfiksuoti Vilniaus MS.

Teigiami statistiškai reikšmingi pokyčiai 19612010 m. visoje Lietuvos teritorijoje dirvožemio paviršiuje nustatyti balandžio mèn., o didesneje jos dalyje - gegužę, liepą ir rugpjūtį (6 pav.). Gruodi-kovą užfiksuotos teigiamos pokyčių tendencijos, tačiau tik kai kuriose stotyse jie yra statistiškai reikšmingi. Nors pokyčiai sausi yra patys didžiausi, tačiau dèl didesnès dirvožemio temperatūros reikšmių sklaidos jie nèra statistiškai reikšmingi. Pavasarị vis anksčiau ištirpstant sniego dangai (dažnai ji būna itin nepastovi) bei ịšalui, dirvožemis pradeda anksčiau ir greičiau šilti, todèl ankstyvą pavasarị dirvožemio paviršiaus temperatūra auga greičiau nei oro. Tuo tarpu birželị ir visais rudens mènesiais pokyčių ženklas skirtingose meteorologijos stotyse yra nevienodas, o absoliuti dauguma kaitos tendenciju yra statistiškai nereikšmingos. Neigiami statistiškai 
Lentelè. Vidutinès metinès dirvožemio temperatūros ir ịšalo rodiklių vidutinis pokytis per dešimtmetị 1961$2010 \mathrm{~m}$. Lietuvos meteorologijos stotyse. Statistiškai reikšmingi pokyčiai paryškinti

Table. Changes per decade in mean annual soil temperature as well as frost duration and depth in Lithuania in 1961-2010. Statistically significant changes are in bold

\begin{tabular}{|c|c|c|c|c|c|c|c|}
\hline \multirow[t]{2}{*}{$\begin{array}{c}\text { Meteorologijos stotys } \\
\text { Meteorological stations }\end{array}$} & $\begin{array}{c}\text { Dirvožemio } \\
\text { paviršius } \\
\text { Soil surface } \\
\end{array}$ & $0,2 \mathrm{~m}$ & $0,8 \mathrm{~m}$ & $1,6 \mathrm{~m}$ & $3,2 \mathrm{~m}$ & \multirow{2}{*}{$\begin{array}{l}\text { Maksimalaus } \\
\text { ičšlo gylis cm } \\
\text { Maximal soil } \\
\text { frost depth, cm }\end{array}$} & \multirow{2}{*}{$\begin{array}{l}\text { İšalo trukmè } \\
\text { dienomis } \\
\text { Soil frost } \\
\text { duration, days }\end{array}$} \\
\hline & \multicolumn{5}{|c|}{${ }^{\circ} \mathrm{C} /$ dešimtmetị $/{ }^{\circ} \mathrm{C} /$ decade } & & \\
\hline Biržai & 0,44 & & & & & -5 & -10 \\
\hline Dotnuva & 0,39 & 0,19 & 0,22 & 0,25 & 0,21 & -7 & -13 \\
\hline Dūkštas & $\mathbf{0 , 2 7}$ & & & & & & \\
\hline Kaunas & 0,50 & 0,17 & 0,23 & 0,23 & 0,22 & -2 & -7 \\
\hline Kybartai & 0,37 & & & & & & \\
\hline Klaipèda & 0,46 & & & & & & \\
\hline Laukuva & 0,42 & & & & & & \\
\hline Lazdijai & 0,37 & 0,29 & 0,30 & 0,27 & - & -10 & -9 \\
\hline Panevėžys & 0,34 & 0,21 & 0,24 & 0,22 & 0,22 & -8 & -8 \\
\hline Raseiniai & 0,40 & & & & & -5 & -8 \\
\hline Šiauliai & 0,40 & 0,30 & 0,29 & 0,24 & 0,27 & -10 & -11 \\
\hline Šilutè & 0,19 & & & & & -3 & -7 \\
\hline Telšiai & 0,40 & 0,33 & 0,36 & 0,28 & 0,23 & -8 & -10 \\
\hline Ukmergè & 0,35 & & & & & -8 & -10 \\
\hline Utena & 0,39 & & & & & -8 & -9 \\
\hline Varèna & 0,34 & & & & & -8 & -10 \\
\hline Vilnius & 0,44 & 0,28 & 0,32 & 0,33 & 0,32 & -8 & -7 \\
\hline
\end{tabular}

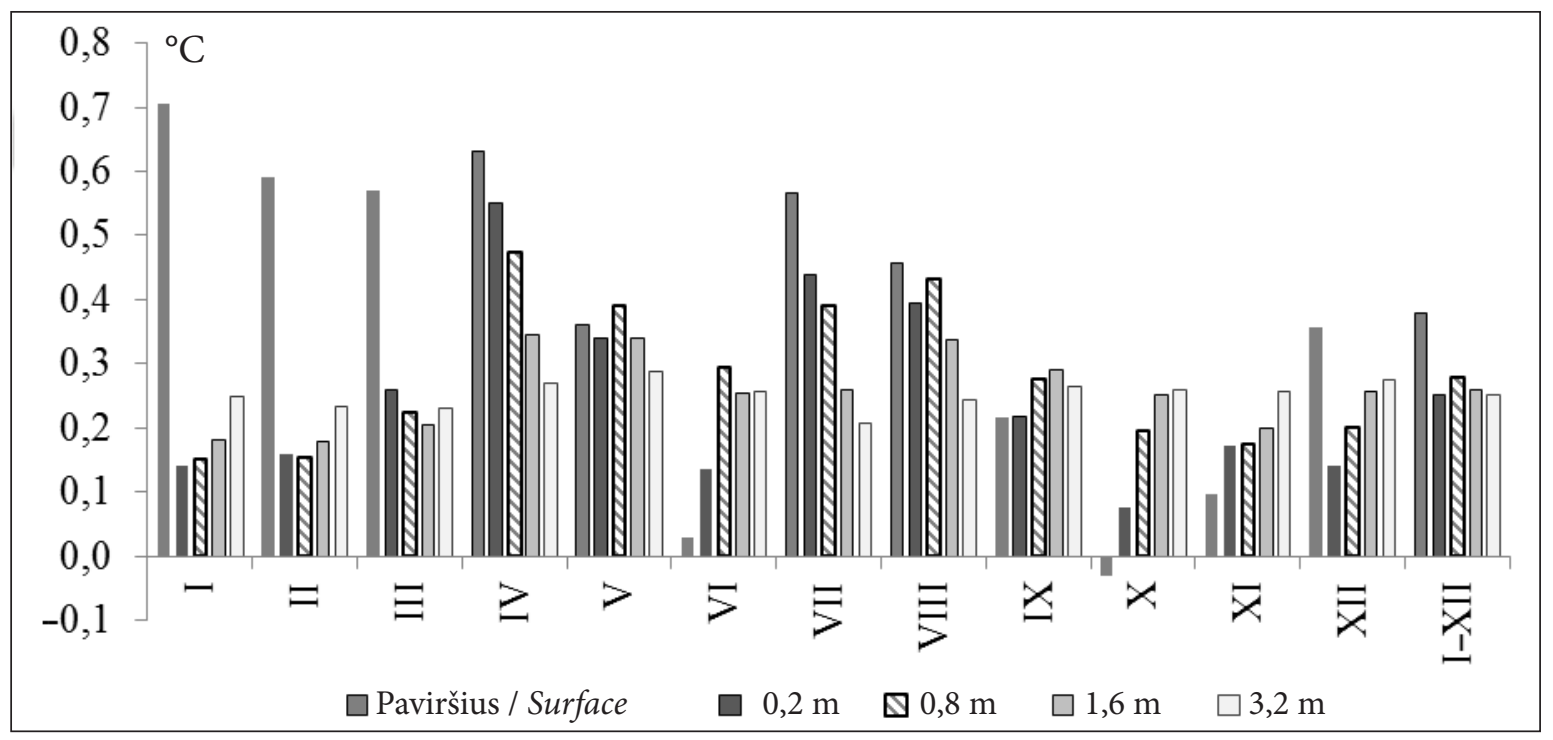

6 pav. Dirvožemio temperatūros kaita $\left({ }^{\circ} \mathrm{C}\right.$ per dešimtmetị) paviršiuje (iš septyniolikos meteorologijos stočių duomenų) įvairiuose gyliuose Lietuvoje (iš septynių meteorologijos stočių duomenų) 1961-2010 m. Statistiškai reikšmingi pokyčiai įreminti

Fig. 6. Soil temperature changes $\left({ }^{\circ} \mathrm{C}\right.$ per decade) at soil surface (according to data from 17 meteorological stations) and in various depths in Lithuania (according to data from seven meteorological stations) in 19612010. Statistically significant trends are framed 
nereikšmingi pokyčiai beveik visoje Lietuvoje užfiksuoti spali, o birželį - pusèje šalies teritorijos.

Vidutinès dirvožemio paviršiaus temperatūros reikšmių kaitos tendencijos yra teigiamos visais metų mėnesiais (išskyrus spalį), o balandị-gegužę ir liepą-rugpjūti pokyčiai yra statistiškai reikšmingi (6 pav.).

Visuose gyliuose, kuriuose matuojama dirvožemio temperatūra, užfiksuotas temperatūros didèjimas, o augimo tempas yra labai panašus $(0,25-$ $0,28^{\circ} \mathrm{C} /$ dešimtmeti) (6 pav.). Šie skaičiai yra mažesni nei užfiksuoti pokyčiai dirvožemio paviršiuje (vidutiniškai $0,4^{\circ} \mathrm{C} /$ dešimtmetį). Gilesniuose dirvožemio sluoksniuose visų ménesių pokyčių tendencijos yra teigiamos. Jei $0,2 \mathrm{~m}$ gylyje statistiškai reikšmingi pokyčiai nustatyti kovą-gegužę ir liepą-rugsèji (analizuojant vidutines reikšmes Lietuvoje pagal septynių stočių vidurkį), tai gilesniuose sluoksniuose statistiškai reikšmingi pasikeitimai užfiksuoti vi- sais metų mènesiais. Tai paaiškinama dirvožemio temperatūros svyravimų mažejjimu didejjant gyliui. 0,2-1,6 m gylyje greičiausiai temperatūra augo balandžio mèn., o mažiausias augimas užfiksuotas sausį. $3,2 \mathrm{~m}$ gylyje labiausiai dirvožemio temperatūra kilo gegužès mẻn., o mažiausia - liepą.

7 pav. pavaizduoti dirvožemio temperatūros profiliai Vilniuje 1961-1985 ir 1986-2010 metais. Labiausiai dirvožemio terminè struktūra pakito vasaros mènesiais. Šiuo metų laikotarpiu nustatyti ryškūs temperatūros pokyčiai visoje dirvožemio storymejje, o gilesniame sluoksnyje jie mažesni. Žiemą didžiausi pokyčiai fiksuoti paviršiuje, o gilesniuose sluoksniuose vidutinè dirvožemio temperatūra pasikeitè nedaug. Pereinamaisiais sezonais (pavasarị ir rudenị) teigiami temperatūros pokyčiai didesni gilesniame sluoksnyje nei paviršiniame.

Augant šaltojo sezono oro temperatūrai, ǐšalo trukmè visoje šalies teritorijoje statistiškai

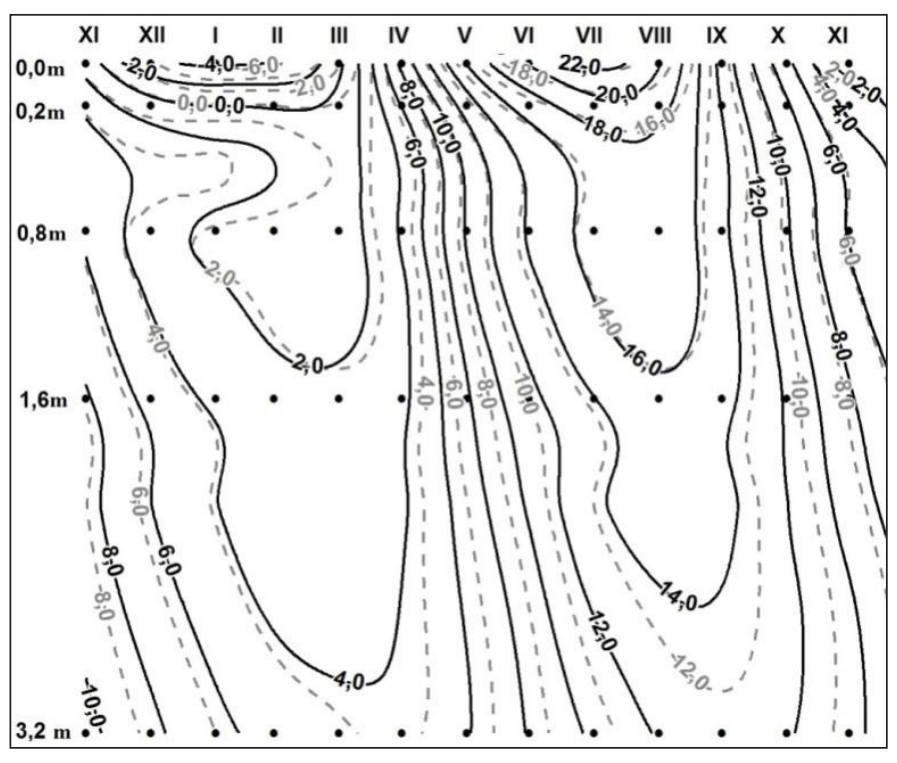

7 pav. Dirvožemio temperatūros profiliai Vilniuje. Punktyrinè linija 1961-1985 m., ištisinè - 1986$2010 \mathrm{~m}$.

Fig. 7. Soil temperature profiles in Vilnius. 19611985 - gray dotted line, 1986-2010 - black solid line

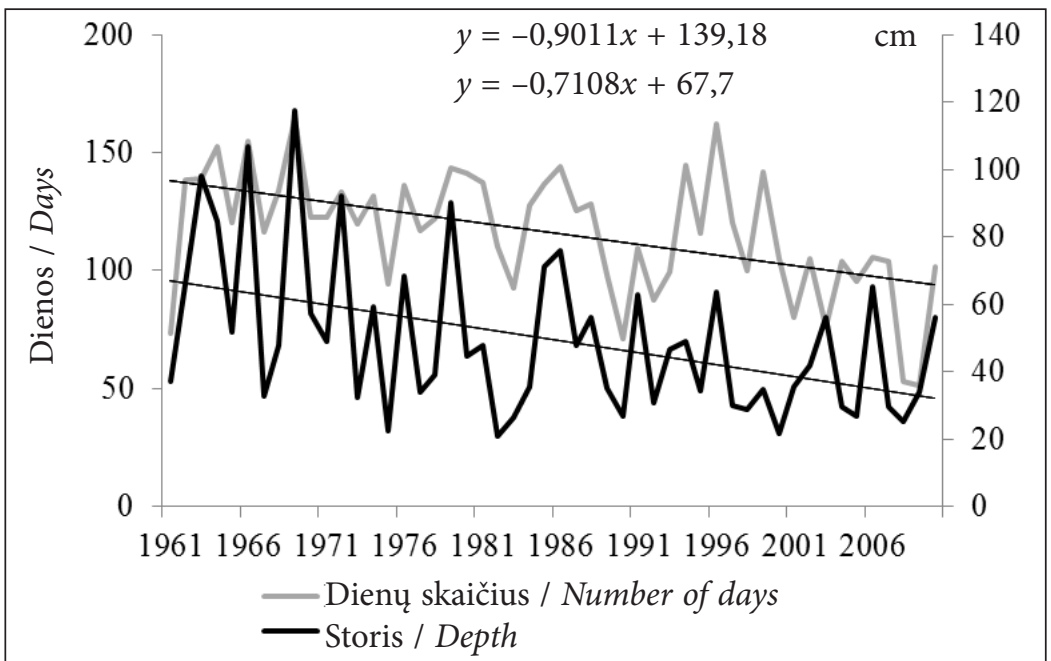

8 pav. Dienų su įšalu skaičiaus ir maksimalaus išalo storio $(\mathrm{cm})$ kaita Lietuvos teritorijoje (iš trylikos meteorologijos stočių duomenų) 1961$2010 \mathrm{~m}$.

Fig. 8. Changes in the number of frost days and maximal frost depth $(\mathrm{cm})$ in Lithuania (according to data from 13 meteorological stations) in 1961-2010 
reikšmingai sumažèjo. Vidutiniai pokyčiai šalies teritorijoje siekia 9 dienas per dešimtmetị (8 pav.). Daugiausia ǐšalo trukmè sumažèjo Dotnuvoje (13 dienų per dešimtmetí), mažiausia - Kaune, Šilutejje ir Vilniuje (7 dienos) (lentelè). Per analizuojamaji laikotarpi maksimalus ǐšalo gylis taip pat mažejo - vidutiniškai Lietuvoje $8 \mathrm{~cm}$ per dešimtmetį. Daugumoje meteorologijos stočių pokyčiai statistiškai reikšmingi (lentelè). Greičiausiai šio rodiklio reikšmè mažėjo Šiauliuose $(11 \mathrm{~cm}$ per dešimtmetị), o mažiausiai - Kaune $(7 \mathrm{~cm})$.

\section{APIBENDRINIMAS IR DISKUSIJA}

Bendri teritorinio oro temperatūros (Galvonaite ir kt., 2007) ir dirvožemio paviršiaus temperatūros pasiskirstymo bruožai Lietuvoje yra artimi. Žiemą oro ir dirvožemio temperatūros izotermų išsidèstymas yra labai panašus, nes svarbiausias veiksnys abiem atvejais yra atstumas nuo santykinai šiltos jūros ir kiek mažiau svarbi yra absoliutaus vietovès aukščio įtaka. Vasarą skirtumai yra didesni, kadangi itin išauga vietos veiksnių ịtaka, iš jų ir dirvožemio granuliometrinès sudèties poveikis. Vasaros mènesiais vidutinè oro temperatūra pajūryje yra mažesnè nei labiau ị rytus nutolusiose šalies teritorijos dalyse, o dirvožemio paviršiaus temperatūra dèl didelio smèlio ir priesmèlio šilumos laidumo, mažos talpos labai išauga (ypač dienos metu) ir yra vidutiniškai didesnè nei likusioje šalies dalyje. Taip pat vasarą aukšta dirvožemio temperatūra išsiskiria Pietų Lietuva. Tai lemia platuma ir su tuo susijęs didesnis saulès aukštis virš horizonto, taip pat smèlio dirvožemiai. Vidutinè metinè dirvožemio paviršiaus temperatūra yra apie $1,5^{\circ} \mathrm{C}$ didesnè nei oro, išmatuota $2 \mathrm{~m}$ aukštyje. Šis skirtumas didejja didejjant aukščiui (Handbook..., 1988). Vidutinè metinè dirvožemio temperatūra įvairiuose gyliuose nuo oro temperatūros skiriasi dar labiau (apie $2{ }^{\circ} \mathrm{C}$ ). Viena svarbiausių priežasčių yra ta, kad susiformavus sniego dangai, paviršiaus temperatūros matavimai vykdomi ant sniego dangos paviršiaus, o ne po ja. Mūsų tyrimas rodo, kad tais metais, kai stora sniego danga išsilaiko ilgai, vidutinès metinès dirvožemio temperatūros skirtumas $0,2 \mathrm{~m}$ gylyje bei paviršiuje gali viršyti net $2{ }^{\circ} \mathrm{C}$, o mažai sniegingais metais skirtis labai mažai arba net paviršiaus temperatūra gali būti šiek tiek didesnè nei gilesniuose sluoksniuose. Nustatyta, kad stora sniego danga gali keletu laipsniu padidinti vidutinę metinę dirvos temperatūrą, o jai plonèjant bei mažejant jos trukmei vidutinè metinè dirvos temperatūra ịvairiuose gyliuose gali sumažèti (Goodrich, 1982; Ling, Zhang, 2007).

Tiriamuoju laikotarpiu (1961-2010) Lietuvoje vidutinè metinè dirvožemio temperatūra statistiškai reikšmingai išaugo. Identiški pokyčiai fiksuoti daugelyje pasaulio šalių - Kanadoje (Beltrami, 2003), Rusijoje (Park ir kt., 2014), Suomijoje (Helama ir kt., 2011) ir kt. Tai rodo, kad dirvos temperatūros kaita yra ryškus globalių pokyčių, vykstančių klimato sistemoje, atspindys.

Nustatyta, kad dirvožemio temperatūros kaita paviršiuje beveik sutampa su oro temperatūros kaitos tendencijomis. Ankstesni tyrimai parode, kad tik birželio ir spalio mèn. kai kuriose meteorologijos stotyse buvo nustatytas nežymus oro temperatūros žemèjimas, o balandị, liepą ir rugpjūtị užfiksuotas statistiškai reikšmingas oro temperatūros augimas visoje Lietuvos teritorijoje (Mickevič, Rimkus, 2013). Labai panašios ir dirvos bei oro temperatūros trendų reikšmès. Vidutinè metinè oro temperatūra daugumoje Lietuvos meteorologijos stočių augo nuo 0,3 iki $0,4^{\circ} \mathrm{C}$ per dešimtmetị. Tai, kad dirvožemio paviršiaus temperatūros trendai beveik (dažniausiai yra nežymiai mažesni) sutampa su oro temperatūros trendais, nustatyta ir kitose šalyse (Jacobs ir kt., 2011; Helama ir kt., 2011).

Gilesniuose dirvos sluoksniuose pokyčiai buvo mažesni $\left(0,25-0,28{ }^{\circ} \mathrm{C} /\right.$ dešimtmetị). Toks trendo reikšmių pasiskirstymas užfiksuotas daugelyje šalių (Glichinsky ir kt., 1998; Zhang ir kt., 2005). Tai dažniausiai aiškinama sniego rodiklių pokyčiais: didejjant sniego dangos nepastovumui bei mažejjant jos storiui ir išsilaikymo trukmei, silpnèja sniego dangos poveikis gilesnių dirvožemio sluoksnių terminiam režimui, todèl žiemos laikotarpiu dirvožemio temperatūra auga daug léčiau nei oro (Zhang ir kt., 2005; Qian, 2011; Mackiewicz, 2012). Kita vertus, tyrimai Rusijoje parodè, kad dideleje šalies teritorijoje sniego storis XXI a. išaugo, todèl dirvos temperatūra 1,6 m gylyje kilo greičiau nei oro temperatūra (Park, 2014). Kita priežastis, lemianti mažesnius temperatūros trendus gilesniuose dirvos sluoksniuose, sietina su kritulių režimo pokyčiais: nuo to priklauso energijos kiekis, kurị dirvožemis panaudoja garinimui, taip pat kinta dirvožemio šilumine talpa (Lin ir kt., 2003; Zhang ir kt., 2005). 
Su išvardytais veiksniais susijusi ir gana ryški sezoninè trendo reikšmiu diferenciacija j̇vairiuose gyliuose - trendo reikšmių maksimumas Lietuvoje didejant gyliui pasislenka $\mathfrak{i}$ antrą pavasario pusę. Tai sietina ir su sniego režimo pokyčiais (Rimkus ir kt., 2014), ir su didele šilumos mainų dirvožemyje inercija. Be to, B. Qian ir kt. (2011) teigia, kad anksčiau ištirpęs sniegas ir didejjanti saulès energija lemia, kad antroje pavasario pusejje dirvožemio įvairiuose gyliuose trendo reikšmès yra panašios ar net didesnès nei oro temperatūros.

Maksimalus į̌salo storis ir trukmè priklauso nuo oro temperatūros, sniego storio ir dirvožemio savybių. Visose Lietuvos meteorologijos stotyse neigiama koreliacija tarp lapkričio-balandžio mèn. oro temperatūros bei įšalo parametrų yra statistiškai reikšminga. Labiausiai įšalo rodikliai priklauso nuo sausio-kovo mèn. oro temperatūros.

Storas įšalo sluoksnis gali susidaryti ir tuo atveju, jei šalčiai prasideda dar nesusiformavus sniego dangai (Osokin ir kt., 2000), o stora mažai šilumai laidi sniego danga gali apsaugoti dirvožemį nuo išsalo sluoksnio storejjimo net ir didelių šalčių metu (Zhang, 2005).

İšalo gylis priklauso ir nuo dirvožemio granuliometrinès sudèties. Yra žinoma, kad sausesnis dirvožemis įšąla greičiau ir giliau nei drègnesnis, kadangi drègnas dirvožemis pasižymi didesne šilumine talpa, lečiau vèsta (Wilis ir kt., 1961).

Nuo XX a. 9-ojo dešimtmečio pabaigos išaugusi žiemos oro temperatūra lèmé, kad visoje Lietuvos teritorijoje sumažèjo išalo trukmè ir gylis. İšalo trukmè statistiškai reikšmingai sumažèjo visose meteorologijos stotyse, o jo storis - daugiau nei dviejuose trečdaliuose šalies teritorijos. 1961-2010 m. nustatytas ịšalo trukmès mažejjimas vidutiniškai 9 dienomis per dešimtmetị yra artimas apskaičiuotam J. Taminsko ir kt. (2005). Mokslininkai nurodo, kad per paskutiniuosius du XX a. dešimtmečius sezoninio ìšalo trukmé sumažèjo dviem savaitėmis.

Vidutiniškai 1961-2010 m. per dešimtmeti Lietuvoje vidutinis maksimalus įšlo storis sumažèjo 8 dienomis. O. W. Frauenfeld ir T. Y. Zhang (2011) nustatè, kad Eurazijoje 1930-2000 m. maksimalus įšalo storis vidutiniškai mažèjo $4,5 \mathrm{~cm}$ per dešimtmeti, o ryškiausi pokyčiai užfiksuoti nuo 7-ojo dešimtmečio pabaigos iki 10-ojo dešimtmečio vidurio. Tiriamojo laikotarpio pradžioje jokių pokyčių neužfiksuota (Frauenfeld, Zhang, 2011). Ryškūs sezoninio maksimalaus įšalo pokyčiai už- fiksuoti ir Rusijoje, kur 1956-1990 m. vidutiniškai šio rodiklio reikšmė sumažejo $34 \mathrm{~cm}$ (Frauenfeld ir kt., 2004). J. Taminskas su bendrautoriais (2006) taip pat nustate maksimalaus įšalo gylio mažejimo tendencijas Lietuvoje XX a. pabaigoje ir susiejo tai su cikliniais oro temperatūros svyravimais. Autoriai teigia, kad XXI a. pradžioje maksimalus įšalo gylis turètų vèl padidèti (Taminskas ir kt., 2006). Mūsų tyrimas tokių XXI a. pradžios tendencijų neatskleidè. Labiau tikètina, kad šylant globaliam ir Lietuvos klimatui sezoninio ìšalo rodikliai dar labiau sumažès (Henry, 2008).

Gauta 20160502

Priimta 20160523

\section{Literatūra}

1. Albergel C., Dutra E., Muñoz-Sabater J., Haiden T., Balsamo G., Beljaars A., Isaksen L., de Rosnay P., Sandu I., Wedi N. 2015. Soil temperature at ECMWF: an assessment using ground based observations. Journal of Geophysical Research: Atmospheres. 120(40): 1361-1373.

2. Beltrami H., Gosselin C., Mareschal J. C. 2003. Ground surface temperatures in Canada: Spatial and temporal variability. Geophysical Research Letters. 30: 1499.

3. Beniston M., Diaz H. F. 2004. The 2003 heat wave as an example of summers in a greenhouse climate? Observations and climate model benistons for Basel, Switzerland. Global and Planetary Change. 44: 73-81.

4. Blum W. E. H. 2005. Soils and climate change. Journal of Soils and Sediments. 5(2): 67-68.

5. Brown P. J., DeGaetano A. T. 2011. A paradox of cooling winter soil surface temperatures in a warming northeastern United States. Agricultural and Forest Meteorology. 151: 947-956.

6. Bukantis A. 1994. Lietuvos klimatas. Vilnius: Vilniaus universiteto leidykla.

7. Davidson E. A., Janssens I. A. 2006. Temperature sensitivity of soil carbon decomposition and feedbacks to climate change. Nature. 440(7081): 165-173.

8. Domisch T., Finér L., Lehto T. 2001. Effects of soil temperature on biomass and carbohydrate allocation in Scots pine (Pinus sylvestris) seedlings at the beginning of the growing season. Tree Physiology. 21(7): 465-472.

9. Euskirchen E., McGuire A. D., Kicklighter D. W., Zhuang Q., Clein J. S., Dargaville R. J., Dye D. G., Kimball J. S., McDonald K. C., Melillo J. M., Romanovsky V. E., Smith N. V. 2006. Importance of recent shifts in soil thermal dynamics on growing season length, productivity, and carbon sequestration 
in terrestrial high latitude ecosystems. Global Change Biology. 12(4): 731-750.

10. Feizienè D., Feiza V., Kadžienė G. 2009. Meteorologinių sąlygų įtaka dirvožemio vandens garų srauto intensyvumui ir $\mathrm{CO}_{2}$ emisijai taikant skirtingas žemès dirbimo sistemas. Žemdirbysté-Agriculture. 96(2): 3-22.

11. Frauenfeld O. W., Zhang T., Barry R. G., Gilichinsky D. 2004. Interdecadal changes in seasonal freeze and thaw depths in Russia. Journal of Geophysical Research. 109: D05101.

12. Frauenfeld O. W., Zhang T. Y. 2011. An observational 71-year history of seasonally frozen ground changes in the Eurasian high latitudes. Environmental Reseasrch Letters. 6: 044024.

13. Galvonaitė A., Misiūnienė M., Valiukas D., Buitkuviené M. S. 2007. Lietuvos klimatas. Vilnius.

14. Gilichinsky D. A., Barry R G., Bykhovets S. S., Zhang T., Zudin S. L., Federov-Dovydod D. G. 1998. A century of temperature observations of soil climate: methods of analysis and long-term trends. Proceedings of the Seventh International Conference on Permafrost, Canada. 313-317.

15. Goodrich L. E. 1982. The influence of snow cover on the ground thermal regime. Canadian Geotechnical Journal. 19(4): 421-432.

16. Haei M., Öquist M. G., Buffam I., Ågren A., Blomkvist P., Bishop K., Löfvenius M. O., Laudom H. 2010. Cold winter soils enhance dissolved organic carbon concentrations in soil and stream water. Geophysical Research Letters. 37: L08501.

17. Haei M., Öquist M. G., Kreyling J., Ilstedt U., Laudon H. 2013. Winter climate controls soil carbon dynamics during summer in boreal forests. Environmental Research Letters. 8: 024017.

18. Handbook of Terrestrial Heat-Flow Density Determination. 1988. Editors: R. Haenel, L. Rybach, L. Stegena (eds.). Springer Netherlands. 487 p.

19. Helama S., Tuomenvirta H., Venäläinen A. 2011. Boreal and subarctic soils under climatic change. Global and Planetary Change. 79: 37-47.

20. Henry H. A. L. 2008. Climate change and soil freezing dynamics: historical trends and projected changes. Climatic Change. 87(3): 421-434.

21. Jacobs A. F. G., Heusinkveld B. G., Holtslag A. A. M. 2011. Long-term record and analysis of soil temperatures and soil heat fluxes in a grassland area, the Netherlands. Agricultural and Forest Meteorology. 151: 774-780.

22. Jungqvist G., Oni S. K., Teutschbein C., Futter M. N. 2014. Effect of climate change on soil temperature in Swedish boreal forests. PLOS ONE. 9(4): e93957.

23. Kaspar T., Bland W. L. 1992. Soil temperature and root growth. Soil Science. 154(4): 290-299.

24. Krotovas A. 2012. Dirvožemio hidroterminis režimas: bakalauro darbas. Vilnius: Vilniaus universitetas.

25. Lehnert M. 2014. Factors affecting soil temperature as limits of spatial interpretation and simulation of soil temperature. Acta Universitatis Palackianae Olomucensis - Geographica. 45(1): 5-21.

26. Lin X., Smerdon J. E., England A. W., Pollack H. N. 2003. A model study of the effects of climatic precipitation changes on ground temperatures. Journal of Geophysical Research. 108(D7): 4230.

27. Ling F., Zhang T. 2007. Modeled impacts of changes in tundra snow thickness on ground thermal regime and heat flow to the atmosphere in Northernmost Alaska. Global and Planetary Change. 57(3-4): 235-246.

28. Lu Y., Xu H. 2014. Effects of soil temperature, flooding, and organic matter addition on $\mathrm{N}_{2} \mathrm{O}$ emissions from a soil of Hongze Lake Wetland, China. The Scientific World Journal. ID272684.

29. Luo L., Robock A., Vinnikov K. Y., Schlosser C. A., Slater A. G., Boone A., Braden H., Cox P., de Rosnay P., Dickinson R. E., Dai Y., Duan Q., Etchevers P., Henderson-Sellers A., Gedney N., Gusev Y. M., Habets F., Kim J., Kowalczyk E., Mitchell K., Nasonova O. N., Noilhan J., Pitman A. J., Schaake J., Shmakin A. B., Smirnova T. G., Wetzel P., Xue Y., Yang Z.-Y., Zeng Q.-C. 2003. Effects of frozen soil on soil temperature, spring infiltration, and runoff: results from the PILPS 2(d) experiment at Valdai, Russia. Journal of Hydrometeorology. 4: 334-351.

30. Mackiewicz M. C. 2012. A new approach to quantifying soil temperature responses to changing air temperature and snow cover. Polar Science. 6(3-4): 226-236.

31. Maljanen M., Kohonen A.-R., Virkajärvi P., Martikainen P. J. 2007. Fluxes and production of $\mathrm{N}_{2} \mathrm{O}$, $\mathrm{CO}_{2}$ and $\mathrm{CH}_{4}$ in boreal agricultural soil during winter as affected by snow cover. Tellus. 59B: 853-859.

32. Melillo J. M., Steudler P. A., Aber J. D., Newkirk K., Lux H., Bowles F. P., Catricala C., Magill A., Ahrens T., Morrisseau S. 2002. Soil warming and carbon-cycle feedbacks to the climate system. Science. 298(5601): 2173-2176.

33. Mickevič A., Rimkus E. 2013. Vidutinès oro temperatūros dinamika Lietuvoje. Geografija. 49(2): 114-122.

34. Öquist M., Laudon H. 2008. Winter soil frost conditions in boreal forests control growing season soil $\mathrm{CO}_{2}$ concentration and its atmospheric exchange. Global Change Biology. 14(12): 2839-2847.

35. Osokin N. I., Samoylov R. S., Sosnovskiy A. V., Sokratov S. A., Zhidkov V. A. 2000. Model of the influence of snow cover on soil freezing. Annals of Glaciology. 31: 417-421.

36. Park H., Sherstiukov A. B., Fedorov A. N., Polyakov I. V., Walsh J. E. 2014. Observation-based assessment of how climate affects trends and variability of soil temperature in Russia. Environmental Research Letters. 9: 064026.

37. Qian B., Gregorich E. G., Gameda S., Hopkins D. W., Wang X. L. 2011. Observed soil temperature trends associated with climate change in Canada. Journal of Geophysical Research: Atmospheres. 116(D2): D02106. 
38. Rimkus E., Kažys J., Butkutẻ S., Gečaitė I. 2014. Snow cover variability in Lithuania over the last 50 years and its relationship with large-scale atmospheric circulation. Boreal Environment Research. 19: 337-351.

39. Stieglitz M., Déry S., Romanovsky V., Osterkamp T. 2003. The role of snow cover in the warming of arctic permafrost. Geophysical Research Letters. 30: 1721.

40. Strömgren M., Linder S. 2002. Effects of nutrition and soil warming on stemwood production in a boreal Norway spruce stand. Global Change Biology. 8(12): 1194-1204.

41. Taminskas J., Švedas K., Konstantinova J. 2005. Sezoninio išalo trukmè Lietuvoje. Geografijos metraštis. 38: 18-28.

42. Taminskas J., Švedas K., Švedienè I. 2006. Sezoninio ǐšalo gylio kaita Lietuvoje. Annales Geographicae. 39: 15-24.

43. Važnevičiūtè A. 2007. Dirvos temperatūra ir jos kaita Lietuvoje 1961-2005 metais: bakalauro darbas. Vilnius: Vilniaus universitetas.

44. Willis W. O., Carlson C. W., Allessi J., Haas H. J. 1961. Depth of freezing and spring run off as reelated to full soil moisture levels. Canadian Journal of Soil Science. 41: 115-123.

45. Zhang Y., Chen W., Smith S. L., Riseborough D. W., Cihlar J. 2005. Soil temperature in Canada during the twentieth century: Complex responses to atmospheric climate change. Journal of Geophysical Research. 110: D03112.

46. Zhang T. 2005. Influence of the seasonal snow cover on the ground thermal regime: An overview. Review of Geophysics. 43: RG4002.

47. Zhang T., Barry R. G., Gilichinsky D., Bykhovets S. S., Sorokovikov V. A., Jingping Y. 2001. An amplified signal of climatic change in soil temperature during the last century at Irkutsk, Russia. Climatic Change. 49: 41-76.

\section{Viktorija Mačiulytė, Egidijus Rimkus \\ SOIL THERMAL REGIME IN LITHUANIA}

\section{Summary}

Soil is one of the main surface components, which interacts with atmosphere, biosphere and hydrosphere. The main goal of this research is to analyze the soil temperature regime and relations with air temperature and soil frost parameters in Lithuania. The measurement results of soil temperature on the surface and at $0.2,0.8,1.6$ and $3.2 \mathrm{~m}$ depths in 17 Lithuanian meteorological stations were used in this study. Mean seasonal soil temperature fluctuations, long-term trends (1961-2010), soil temperature connections with air temperature, maximum frost depth and duration were analyzed.

The average annual soil surface temperature was equal to $7.9^{\circ} \mathrm{C}$ and in deeper layers $(0.2,0.8,1.6$ and $3.2 \mathrm{~m}$ deep) to $8.3^{\circ} \mathrm{C}$ in Lithuania in $1981-2010$. Soil surface, 0.2 and $0.8 \mathrm{~m}$ depth temperature had a greater correlation with the air temperature of the same month, while in deeper layers soil temperature fluctuations were delayed relative to the surface: by one month at $1.6 \mathrm{~m}$ and by $2-4$ months at $3.2 \mathrm{~m}$ depth.

During the study period (1961-2010), the annual mean surface temperature in Lithuania increased significantly $\left(0.4^{\circ} \mathrm{C}\right.$ per decade). The rate of changes of soil temperature in deeper layers varied from $0.26{ }^{\circ} \mathrm{C}$ $(0.2 \mathrm{~m})$ to $0.29^{\circ} \mathrm{C}(0.8 \mathrm{~m})$ per decade. Positive statistical significant changes of soil surface temperature in all stations were found in April, and in a large part of the territory in May, July and April. Negative trends were determined in almost all stations in October, and in half of the stations in June. Only positive changes were identified in deeper layers. Most of them were statistically significant.

The average frost duration varied from 90 days (western part) to 115 days (north-eastern part). The maximum average frost depth was found in Lazdijai $(55 \mathrm{~cm})$, while the smallest in Panevezzys $(29 \mathrm{~cm})$. Soil frost parameters (maximum depth and duration) depended on cold season's (November-April) air temperature. The negative linear correlation coefficients between cold season's air temperature and soil frost duration as well as maximum frost depth were statistically significant $(-0.72$ and -0.71 , respectively). As a result of air temperature rise, negative tendencies of soil frost parameters were observed. Frost duration decreased statistically significantly (by 9 days per decade on average) in the whole Lithuanian territory in 1961-2010, while the negative changes of maximum frost depth (approximately by $8 \mathrm{~cm}$ per decade) were statistically significant in most of meteorological stations.

Key words: soil temperature, soil frost, climate change 